\title{
A brief history of peer-reviewed mountain journals: how platforms for knowledge relevant to sustainable mountain development emerged
}

\author{
Anne B. Zimmermann, Susanne Wymann von Dach, Sarah-Lan Mathez-Stiefel, David Molden \\ \& Thomas Breu
}

Keywords: publishing, peer review, mountains, interdisciplinarity, transdisciplinarity, sustainable development

\section{Abstract}

Dedicated academic mountain journals emerged as of the beginning of the $20^{\text {th }}$ century from a need to collect very diverse work focusing on mountains as a fascinating and challenging environment as well as a place of unique livelihood systems. We present a brief overview of the four peer-reviewed, indexed journals that exist today for mountain scholarship and show how strongly connected they are with an understanding of science linked to sustainable development. This specificity is confirmed by the fact that - as of the 1970s - a number of leading mountain scholars from around the world started engaging not only in research but also in policy action to ensure that mountains and mountain development are taken into account in key global sustainable development documents.

What has been the added value of mountain journals and what was the motivation for launching them? On the occasion of eco.mont's tenth anniversary, the editors of the journal Mountain Research and Development were asked to tell the story of mountain journals. The story starts with the Revue de géographie alpine, launched by the French geographer Raoul Blanchard in 1913 with the double aim of bringing together work on the European Alps (and on the French Alps in particular) and making it accessible to a broader scientific public (RGA 1913). Publication of mountain research in specifically dedicated journals thus began as a European geographer's concern with a fascinating and often challenging environment in which human communities had developed well-adapted and often unique livelihood systems and cultures. This concern with both environmental and developmental issues, along with a recognition of the need to make research relevant to society, has been a key characteristic of mountain journals, of which the following are the main indexed ones published in English: Journal of Alpine Research / Revue de géographie alpine (JAR-RGA); Mountain Research and Development (MRD); Journal of Mountain Science (JMS); and the now ten-year-old eco.mont. Here is their story in a nutshell.

Journal of Alpine Research / Revue de géographie alpine (JAR-RGA)

Published since its inception by the Institut de Géographie Alpine at the University of Grenoble, France, JAR-RGA became a bilingual journal in 2004. The focus remained the Alpine Arc in Europe until 2012, with occasional articles on other mountain regions worldwide included in focus issues to enable a comparative perspective on mountain issues. On the occasion of the journal's one-hundredth anniversary in 2013, JAR-RGA's editors decided to go open access and make English the first language of articles. They also decided to publish translations into other European Alpine languages - French, German, Italian, and
Spanish - with a view to "opening French-language thinking to the world even more" (JAR-RGA 2018). Authors' affiliations are now thoroughly international and the quarterly issues cover a remarkable variety of topics and concerns, often in thematic issues.

\section{Mountain Research and Development (MRD)}

In the early 1970s, a large group of scientists from several countries involved in UNESCO's innovative interdisciplinary Man and the Biosphere program most of them geographers as well - joined efforts to organize international conferences focusing on environmental concerns in mountains that are of significance also to lowland communities (Ives 1981). The focus on mountains, highland-lowland interactions, and development in mountains thus became a worldwide scientific concern in the context of the nascent global sustainable development debate. MRD emerged from this international research collaboration with a development concern in 1981. MRD's founding editor Jack Ives declared: "The challenge to influence mountain management by urging, and providing, a sound scientific base for decision making lies at the heart of our purpose - to seek a better balance between mountain environments, human welfare, and development of resources" (Ives 1981, p. 4). From the beginning, MRD was distributed free of charge in developing countries (Ives 1990). Mountain scientists' development concerns also translated into a joint effort with development and policy actors to ensure that Chapter 13 was included in Agenda 21 by 1992 (Mathieu 2011; Messerli 2012; Price 2015).

To address salient societal issues, in 2000 MRD launched a new section presenting transformation knowledge, with articles targeting a much broader audience including decision- and policy-makers. It was later enhanced by a double-blind peer review process - pioneering what is now being internationally called for (Future Earth 2014): transformation knowledge as key for sustainable development. The established academic section offering mainly systems knowledge also now at- 
tracted and supported more authors from the global South; and as of 2009, MRD went open access, as a means of making scientific knowledge and development debates entirely accessible to the South. In 2013, then-editors-in-chief Hans Hurni (CDE, University of Bern) and David Molden (ICIMOD) launched a third peer-reviewed section presenting target knowledge (Hurni et al. 2013). Thus, the journal now offered all three dimensions of knowledge for sustainable mountain development.

eco.mont - Journal on Protected Mountain Areas Research and Management

The need for linking science and practice is also what drove the launching in 2008 of eco.mont - Journal on Protected Mountain Areas Research and Management, published open access twice a year. Representing a vibrant European scientific community concerned with the future of mountains, founding editors Axel Borsdorf (University of Innsbruck) and Günter Köck (Austrian Academy of Sciences) aimed to offer "a platform specifically for scientists and practitioners working in and on protected mountain areas in Europe and overseas", calling for papers from both the academic and practice communities. eco. mont has succeeded in publishing an impressively large number of articles despite the comparatively narrow definition of its scope - arguably a sign of the importance of mountains in efforts to achieve SDG 15 of the 2030 Agenda, i. e. to conserve our natural environment while offering new development options to humanity. This mountain journal thus also reveals a strong commitment to disseminating knowledge for sustainable mountain development, and to using adequate modes of enhancing this knowledge through rigorous review that takes into account interdisciplinary and transdisciplinary approaches (Borsdorf \& Köck 2008).

\section{Journal of Mountain Science (JMS)}

Meanwhile, on the other side of the earth, in China, research on mountain environments and mountain development had obviously also become a strong concern. In 2004, JMS was launched by the Institute of Mountain Hazards and Environment, Chinese Academy of Sciences, with the explicit aim of enhancing international academic exchange on mountain research and integrating Chinese research into the global debate. The journal is not open access but subscriptions are supported in developing countries by the United Nations University. The journal started as a quarterly from 2004 until 2010, then published six issues a year until 2015, and since then has been appearing as a monthly journal. Its objective to publish research and technical papers on mountain environment, mountain ecology, mountain hazards, mountain resources, and mountain development, with a clear predominance of disciplinary papers, reveals a different understanding of science for sustainable development, with less emphasis on transdisciplinarity and transformative science than MRD and eco.mont.
It is thus obvious that sustainable mountain development matters to scientists worldwide. Clearly, English has become the lingua franca of their work whether for better or for worse is not something to be debated here. This led several national and regional mountain research communities to decide to publish their work in English. The most recent case is that of the Russian journal Sustainable Development in Mountain Territories, launched by the North Caucasian Institute of Mining and Metallurgy (State Technological University) as a quarterly in 2009: it is now seeking ways of making key articles in Russian become available to an English-speaking audience, while also translating selected articles from MRD for its Russian scientific readership.

As a final note, in addition to consulting mountain journals (Table 1), readers looking for work relevant to mountains and mountain development will certainly also find articles in disciplinary journals explicitly or not explicitly devoted to mountains (Körner 2009; Sarmiento \& Butler 2011). These journals have also been informing debates about mountain-specific challenges and dynamics. So what is the advantage of specific mountain journals? They bring together knowledge from different disciplines to strengthen the debate and the knowledge on mountain-specific challenges, also integrating the different views in one place. This integration and contextualization of knowledge is crucial for transformation towards sustainable development.

\section{References}

Borsdorf, A. \& G. Köck 2008. Editorial. eco.montJournal on Protected Mountain Areas Research and Management 1(1): 3-8.

Future Earth 2014. Future Earth Strategic Research Agenda. Paris.

Hurni, H., D. Molden, A. Zimmermann \& S. Wymann von Dach 2013. MountainNotes becomes MountainAgenda: MRD's third peer-reviewed section. Mountain Research and Development 33(4): 362-363.

Ives, J.D. 1981. Editorial. Mountain Research and Development 1(1): 3-4.

Ives, J.D. 1990. Editorial. Mountain Research and Development 10(1): 1-1.

JAR-RGA [Journal of Alpine Research / Revue de géographie alpine] 2018. [Journal website]. http:// journals.openedition.org/rga/ (accessed 01/02/2018)

Körner, C. 2009. Global statistics of "mountain" and "alpine" research. Mountain Research and Development 29(1): 97-102.

Mathieu, J. 2011. The globalisation of perception. In: The Third Dimension: A Comparative History of Mountains in the Modern Era. Translated by K. Brun. Cambridge.

Messerli, B. 2012. Global change and the world's mountains. Mountain Research and Development 32(S1): S55-S63. 
Price, M.F. 2015. Mountains: A Very Short Introduction. Oxford, U.K..

RGA [Revue de géographie alpine] 2013. Préliminaire. Recueil des travaux de l'Institut de géographie alpine [Revue de géographie alpine] 1(1): 1-3. Available at: http://www.persee.fr/doc/rga_0249-6178_1913_ num_1_1_5573 (accessed on 10/02/2018.)

Sarmiento, F.O. \& D.R. Butler 2011. Where do mountain geographers publish? Mountain Research and Development 31(1): 61-67.

\section{Authors}

Anne B. Zimmermann - corresponding author ${ }^{1}$

is MRD Associate Editor and senior research scientist at CDE, where she co-leads the Education for Sustainable Development cluster. Her research and teaching focuses on inter- and transdisciplinary approaches and on research and education for sustainable development. E-mail:mrd-journal@cde.unibe.ch

\section{Susanne Wymann von Dach}

a geographer by training, is senior research scientist at the Centre for Development and Environment (CDE) and MRD Associate Editor. Her research focuses on communication and innovation for, and transformation processes towards, sustainable mountain development.

\section{Sarah-Lan Mathez-Stiefel ${ }^{1,2}$}

is senior research scientist at CDE, University of Bern, and researcher at the World Agroforestry Cen- tre; she is also MRD Associate Editor. As an ethnobiologist and human geographer, her research focuses on the relationships between human societies and their natural environment.

\section{David Molden ${ }^{3}$}

is the Director General of the International Centre for Integrated Mountain Development (ICIMOD), and MRD Editor-in-Chief. He specializes in water resources management and sustainable mountain development with an interest in transdisciplinary work to transform knowledge into impact.

\section{Thomas Breu'}

is Professor of Sustainable Development and Director of the Centre for Development and Environment (CDE), University of Bern. He is also MRD Editor-in-Chief. He conducts research on the effects of globalization on natural resources and livelihoods in developing countries.

${ }^{1}$ Centre for Development and Environment (CDE), MRD Editorial Office, University of Bern, Hallerstrasse 10, 3012 Bern, Switzerland

${ }^{2}$ World Agroforestry Centre (ICRAF), c/o CIP, av. La Molina 1895, P.O. Box 1558 Lima 12, Peru

${ }^{3}$ International Centre for Integrated Mountain Development (ICIMOD), Kathmandu, Nepal 
Table 1 - Overview of indexed mountain journals with a global reach, in chronological order of their emergence. The last rows indicate two disciplinary journals that are bighly relevant to mountains; admittedly, many more could be listed.

\begin{tabular}{|c|c|c|c|c|c|c|c|}
\hline Title & \begin{tabular}{|l|} 
Exists \\
since
\end{tabular} & Weblink & Founding Editors & Editors-in-Chief & Publisher & \begin{tabular}{|l|} 
Impact \\
factor 2016
\end{tabular} & $\begin{array}{l}\text { Open } \\
\text { access? }\end{array}$ \\
\hline $\begin{array}{l}\text { Revue de géographie } \\
\text { alpine; now Journal } \\
\text { of Alpine Research / } \\
\text { Revue de géographie } \\
\text { alpine (JAR-RGA) }\end{array}$ & 1913 & $\begin{array}{l}\text { http://journals. } \\
\text { openedition.org/rga/ }\end{array}$ & $\begin{array}{l}\text { Raoul Blanchard, } \\
\text { University of Grenoble }\end{array}$ & $\begin{array}{l}\text { Dominique Baud, } \\
\text { Grenoble Alpes Uni- } \\
\text { versity, } \\
\text { Sylvie Duvillard, } \\
\text { Grenoble Alpes Uni- } \\
\text { versity, } \\
\text { Coralie Mounett, } \\
\text { Grenoble Alpes Uni- } \\
\text { versity }\end{array}$ & $\begin{array}{l}\text { OpenEdition for Asso- } \\
\text { ciation pour la Diffusion } \\
\text { de la Recherche Alpine } \\
\text { (ADRA) }\end{array}$ & 0.365 & Yes \\
\hline $\begin{array}{l}\text { Mountain Research } \\
\text { and Development } \\
\text { (MRD) }\end{array}$ & 1981 & $\begin{array}{l}\text { http://www.mrd-journal. } \\
\text { org/ }\end{array}$ & $\begin{array}{l}\text { Jack Ives, } \\
\text { Institute of Arctic and } \\
\text { Alpine Research, } \\
\text { University of Colorado } \\
\text { Boulder }\end{array}$ & $\begin{array}{l}\text { Thomas Breu, } \\
\text { Centre for Develop- } \\
\text { ment and Environment, } \\
\text { University of Bern, } \\
\text { David Molden, } \\
\text { Integrated Centre for } \\
\text { International Mountain } \\
\text { Development (ICIMOD) }\end{array}$ & $\begin{array}{l}\text { BioOne for Interna- } \\
\text { tional Mountain Society } \\
\text { (IMS) }\end{array}$ & 1.149 & Yes \\
\hline $\begin{array}{l}\text { eco.mont - Journal } \\
\text { on Protected Moun- } \\
\text { tain Areas Research } \\
\text { and Management }\end{array}$ & 2008 & $\begin{array}{l}\text { ecomont. } \\
\text { mountainresearch.at }\end{array}$ & $\begin{array}{l}\text { Axel Borsdorf, } \\
\text { Institute of Geography, } \\
\text { University of Innsbruck, } \\
\text { Günter Köck, } \\
\text { Austrian Academy of } \\
\text { Sciences (ÖAW) }\end{array}$ & $\begin{array}{l}\text { Valerie Braun, } \\
\text { Institute for Interdiscipli- } \\
\text { nary Mountain Research } \\
\text { ÖAW, } \\
\text { Martin Coy, } \\
\text { Institute of Geography, } \\
\text { University of Innsbruck, } \\
\text { Günter Köck, } \\
\text { Institute for Interdis- } \\
\text { ciplinary Mountain } \\
\text { Research, ÖAW }\end{array}$ & $\begin{array}{l}\text { Austrian Academy of } \\
\text { Sciences and University } \\
\text { of Innsbruck }\end{array}$ & 0.333 & Yes \\
\hline $\begin{array}{l}\text { Botanica helvetica } \\
\text { (until 2010); Alpine } \\
\text { Botany (since 2011) }\end{array}$ & 1890 & $\begin{array}{l}\text { http://www.springer. } \\
\text { com/life+sciences/ } \\
\text { plant+sciences/journal/35 }\end{array}$ & $\begin{array}{l}\text { Carl Schröter, } \\
\text { ETH Zurich, } \\
\text { Eduard Fischer, } \\
\text { University of Bern }\end{array}$ & $\begin{array}{l}\text { Jürg Stöcklin, } \\
\text { Institute of Botany, } \\
\text { University of Basel }\end{array}$ & $\begin{array}{l}\text { Springer for Swiss } \\
\text { Botanical Society }\end{array}$ & 2.281 & No \\
\hline $\begin{array}{l}\text { Arctic and Alpine } \\
\text { Research (until 1998); } \\
\text { Arctic, Antarctic and } \\
\text { Alpine Research, an In- } \\
\text { terdisciplinary Journal } \\
\text { (since 1999) }\end{array}$ & 1969 & http://aaarjournal.org/ & $\begin{array}{l}\text { Jack D. Ives, } \\
\text { Institute of Arctic and } \\
\text { Alpine Research, } \\
\text { University of Colorado } \\
\text { Boulder }\end{array}$ & $\begin{array}{l}\text { William D. Bowman, } \\
\text { Department of Ecol- } \\
\text { ogy and Evolutionary } \\
\text { Biology, University of } \\
\text { Colorado Boulder } \\
\text { Anne E. Jennings } \\
\text { Department of Geologi- } \\
\text { cal Sciences, University } \\
\text { of Colorado Boulder }\end{array}$ & $\begin{array}{l}\text { Taylor \& Francis for } \\
\text { Institute of Arctic and } \\
\text { Alpine Research, } \\
\text { University of Colorado } \\
\text { Boulder }\end{array}$ & 1.782 & $\begin{array}{l}\text { Yes, as } \\
\text { of } 2018\end{array}$ \\
\hline
\end{tabular}

